\title{
PEMANFAATAN MEDIA SOSIAL DAN PELATIHAN MANAJEMEN USAHA BAGI PENGRAJIN TENUN TRADISIONAL DI DESA WABULA BUTON
}

\author{
Ansar Suherman, Sry Mayunita, dan Mahyudin Mahyudin \\ Program Studi Ilmu Komunikasi, Fakultas Ilmu Sosial dan Ilmu Politik \\ E-mail: ansar.suherman@yahoo.co.id
}

\begin{abstract}
ABSTRAK. Usaha kecil menengah termasuk industri rumah tangga yang terdapat di daerah-daerah di Indonesia mengalami permasalahn yang hampir sama yakni rendahnya produktifitas yang salah satunya disebabkan oleh manajemen usaha yang masih sangat tradisional dan belum adanya pemanfaatan atau penggunaan teknologi informasi dan komunikasi untuk mendukung kegiatan promosi barang atau jasa yang dihasilkan. Permasalahan yang ditemui di pada UKM yang menjadi mitra dalam program ini adalah Manajemen usaha yang dijalankan masih sangat sederhana, belum memiliki sistem pembukuan yang baik dan rapi, sehingga keuntungan maupun kerugian tidak dapat terdeteksi dengan baik, dan jaringan pemasaran yang dimiliki sangat terbatas, serta belum memiliki kemampuan penggunaan Teknologi Informasi sebagai media promosi dan pemasaran. Pelatihan manajemen usaha dan pelatihan pemanfaatan tekonologi informasi dan komunikasi berupa pemanfaatan media sosial dengan memaksimalkan jejaring-jejaring sosial diharapkan mampu meningkatkan omset atau tingkat produktifitas para mitra. Dengan tujuan kegiatan ini, dapat memberikan solusi berupa kemampuan membuat pembukuan, kemampuan teknis mendapatkan bantuan usaha dari pihak lain, dan adanya motivasi berusaha.
\end{abstract}

Kata kunci: Media Sosial; Manajemen Usaha; Kain Tenun Tradisional.

ABSTRACT. Small and medium enterprises, including home industries in regions in Indonesia, experience almost the same problems, namely low productivity, one of which is caused by business management that is still very traditional and the absence of use or use of information and communication technology to support goods promotion activities or services produced. The problem encountered by partners in this program is that the business management carried out is still very simple, not having a good and neat bookkeeping system, so that profits and losses cannot be detected properly.Their marketing network owned is very limited, and they do not have the ability to use technology Information as a media for promotion and marketing. Business management training and training in the use of information and communication technology in the form of using social media by maximizing social networks is expected to increase turnover or productivity levels of partners. With the aim of this activity, can provide solutions in the form of the ability to make bookkeeping, technical ability to get business assistance from other parties, and the motivation.

Key word: Social Media; Business Management; Traditional Woven.

\section{PENDAHULUAN}

Kabupaten Buton adalah wilayah bekas Kerajaan/ Kesultanan Buton yang memiliki banyak sekali warisanwarisan budaya dari leluhur. Dulunya Kabupaten Buton adalah pemilik benteng terluas di dunia, yang kemudian beralih ke Kota Buton karena terjadi pemekaran daerah otonomi baru. Daerah ini juga menawarkan begitu banyak potensi wisata budaya diantaranya adalah Kerajinan Kain tenun tradisional Buton. Dulunya ada banyak pengrajin kain tenun tradisional Buton, namun seiring dengan perkembangan jaman, karena ketidakmampuan bersaing dengan gempuran produksi massal jenis-jenis kain yang lebih modern serta ketidakmampuan dalam melakukan promosi yang lebih efektif, maka perlahan demi perlahan para pengrajin kain tenun tradisional Buton mulai meninggalkan pekerjaannya tersebut karena tidak dapat lagi dijadikan sebagai sumber dalam memenuhi kebutuhan ekonomi sehari-hari.

Makna dan fungsi budaya masyarakat buton melekat pada karya indah kain tenunannya. Salah satunya dapat anda lihat dalam motif Betano Walona Koncuapa, terinspirasi dari warna abu halus yang melayang-layang hasil pembakaran semak saat membuka ladang. Ada juga yang fungsinya sebagai penunjuk strata sosial dalam masyarakat Buton seperti pada motif Kasopa yang sederhana, biasa dipakai oleh perempuan kebanyakan. Ada pula motif Colo Makbahu atau korek basah, motif Delima Bongko (delima busuk), motif Delima Sapuua, dan masih banyak lagi motif lainnya. Motif yang lebih rumit biasa disebut Kumbaea. Sementara itu, motif Kumbaea yang didominasi warna perak biasanya dipakai oleh perempuan dari golongan bangsawan dengan gelar Wa Ode.

Kain Tenun Buton digunakan dalam setiap upacara adat dan ritual keagamaan. Menurut masyarakat Buton, jika kain tenun tersebut tidak disertakan dalam setiap upacara adat dan ritual maka hakikat dan nilai dari upacara dan ritual tersebut dinilai kurang sakral.

Selain sebagai perekat sosial, tenun Buton juga dianggap mampu menjadi identitas diri, karena bagi orang Buton, pakaian tidak hanya sebagai pelindung tubuh dari terik matahari dan dinginnya angin malam, tetapi juga sebagai identitas diri. Dengan melihat pakaian yang dikenakan oleh wanita Buton misalnya, kita bisa mengetahui apakah dia telah menikah atau belum. Selain itu, dari pakaian mereka juga bisa menandakan perempuan tersebut berasal dari golongan awam atau bangsawan

\section{Peranan Tenun Buton dalam Pembangunan Daerah}

Karena pentingnya peranan kain tenun dalam kehidupan masyarakat Buton, sekaligus juga untuk melestarikannya maka sedari kecil (usia 10 tahun) 
para wanita Buton sudah diajari untuk menenun. Tidak hanya masyarakat biasa saja yang trampil menenun, bahkan konon anak dan istri Sultan Buton juga mahir mengerakkan tangan mereka untuk menenun.

Dahulu kain tenun Buton dipakai sebagai pelengkap aktivitas budaya dan ritual adat serta agama. Akan tetapi, kini kain tenun khas Buton sudah dapat dijumpai dalam berbagai bentuk dan kegunaan misalnya pada tas, sarung, selendang, tirai, taplak meja, sarung bantal, dan sebagai hiasan dinding. Kain tenun Buton dapat ditemukan dengan mudah di Kabupaten Buton, yang menjadi pusat kerajinan di Pulau Buton.

Terkait dengan keberadaan para pengrajin kain tenun tradisional Buton ini, berdasarkan hasil obsersi awal yang dilakukan, bahwa pada tahun 2000 masih ada sekitar 21 kelompok pengrajin kain tenun tradisional Buton, namun pada tahun 2016 hanya tersisa 8 kelompok saja (Disperindagkop Buton, 2016). Padahal keberadaan kelompok-kelompok pengrajin tersebut yang dikategorikan sebagai kelompok Usaha Kecil \& Menengah (UKM) mempunyai peran yang strategis dalam pembangunan ekonomi nasional, oleh karena selain berperan dalam pertumbuhan ekonomi dan penyerapan tenaga kerja juga berperan dalam pendistribusian hasilhasil pembangunan.

Lapangan kerja di Indonesia $30 \%$ berada di sektor formal dan $70 \%$ di sektor non formal. Jika dilihat dari unsur sumbangan antar pelaku usaha, lapangan kerja sektor formal terdiri dari $0,55 \%$ disediakan oleh usaha besar, usaha menengah $11,01 \%$ dan usaha kecil menyumbang $18,44 \%$ dari seluruh lapangan kerja formal. Lapangan kerja non formal sebesar 70\% disediakan oleh usaha kecil yang tergolong dalam usaha mikro dan gurem. Hal ini berarti usaha kecil dan menengah telah mengisi sekitar $85 \%$ dari lapangan kerja yang ada di Indonesia (BPS, 2011).

Ada beberapa kegiatan ekonomi produktif di Kabupaten Buton yang secara umum terus bertahan, khususnya kegiatan usaha kecil menengah yaitu berbagai industri kerajinan. Industri kerajinan yang ada di wilayah Buton diantaranya kerajinan kain tenun Buton, kerajinan gerabah, kerajinan berbahan kayu, dan berbagai industri makanan tradisional. Salah satu produk unggulan dari daerah Buton adalah produk kerajinan Kain Tradisional Buton. Dalam pelaskanaan upacara-upacara tradisional yang dilakukan oleh masyarakat Buton, keberadaan kain khas tradisional Buton adalah sesuatu yang wajib hukumnya, sehingga keberadaan para pengrajin kain tenun Buton tetap masih dibutuhkan oleh masyarakat.

Industri kecil Kain Tenun Buton yang menjadi mitra dalam kegiatan PKM ini adalah UKM "Kumaha Mandiri" dan UKM "Wabula Permai" yang keduanya berada di Desa Wabula Kecamatan Wabula Kabupaten Buton. Kedua UKM yang menjadi mitra adalah UKM kerajinan kain tenun tradisional Buton yang dimiliki oleh Ibu Hariani (UKM I) dan Ibu Wa Nuu (UKM II). Kedua
UKM tersebut saling bekerja sama, terutama apabila salah satu UKM tidak dapat memenuhi jumlah pesanan, maka sebagian pesanan akan diberikan kepada UKM yang lain. UKM I memiliki tenaga kerja sebanyak 3 orang sedangkan UKM II memiliki tenaga kerja sebanyak 4 orang yang merupakan warga desa Wabula tempat UKM tersebut berada.

Usaha yang dijalankan kedua UKM ini merupakan usaha keluarga dan kepemilikan modal adalah modal pribadi, sehingga manajemen yang dijalankan juga masih sangat sederhana. Kedua UKM belum memiliki struktur organisasi yang baik, sehingga posisi pemilik disamping sebagai pimpinan juga merangkap sebagai manajer. Kedua UKM belum memiliki sistem pembukuan yang baik dan rapi, sehingga tidak tampak jelas keuntungan atau kerugian yang mereka dapatkan. Selain itu, pemanfaatan media massa sebagai instrumen dalam melakukan promosi dan pemasaran belum dilakukan. Pemanfaatan kain tenun tradisional Buton ini digunakan untuk banyak hal, diantaranya: sarung, baju, topi, selendang, tas, dan sebagainya. Harga kain tradisional Buton berkisar antara Rp. 100,000.- sampai dengan Rp. 250,000.-. perbedaan harga tersebut berdasarkan motif dan bahan baku yang digunakan. Setiap bulan masing-masing UKM mampu membuat 10 helai kain tradisional dengan ukuran 2 meter. Pemasaran produk dilakukan belum dengan maksimal sebab hanya mengandalkan pesanan orang, mengikuti pameran, dan dititipkan ke pengepul.

KegiataninidiusulkanolehtimpelaksanaPengabdian kepada Masyarakat dari Program Studi Ilmu Komunikasi dan Program Studi Ilmu Pemerintahan Fakultas Ilmu Sosial dan Ilmu Politik Universitas Muhammadiyah Buton. Tim pelaksana ini terdiri dari 3 orang dosen. Masing-masing personil tim ini memiliki bidang keahlian yang berbeda-beda yaitu Ilmu Komunikasi, Manajemen, dan Administrasi Pembangunan. Salahsatu prestasi terbaru dari Lembaga Penelitian dan Pengabdian pada Masyarakat (LPPM) Universitas Muhammadiyah (UM) Buton adalah berhasil menaikkan status lembaganya dari Status BINAAN menjadi MADYA. LPPM UM. Buton sebagai lembaga yang menangani kegiatan penelitian dan pengabdian kepada masyarakat menjadi tempat beranaungnya kegiatan ini dalam rangka suksesnya kegiatan nantinya.

Lembaga Penelitian dan Pengabdian pada Masyarakat Universitas Muhammadiyah Buton dapat meningkatkan sumber daya manusia dengan tujuan untuk membentuk atau mengembangkan sekelompok masyarakat yang mandiri secara ekonomi; membantu menciptakan ketentraman, dan kenyamanan dalam kehidupan bermasyarakat; serta meningkatkan keterampilan berpikir, membaca dan menulis atau keterampilan lain yang dibutuhkan.

Kinerja Lembaga Penelitian dan Pengabdian pada Masyarakat Universitas Muhammadiyah Buton dalam bidang kegiatan Pengabdian pada Masyarakat adalah sangat baik. Pihak Lembaga Penelitian dan Pengabdian 
pada Masyarakat senantiasa memberikan semangat dan motivasi kepada seluruh dosen untuk melaksanakan program pengabdian kepada masyarakat dalam bentuk apapun. Hal ini diwujudkan setiap tahun pihak Lembaga Penelitian dan Pengabdian pada Masyarakat Universitas Muhammadiyah Buton menawarkan hibah pengabdian kepada seluruh dosen dengan nama program Pengabdian pada Masyarakat Internal yang mencakup Pengabdian pada Masyarakat unggulan, Pengabdian pada Masyarakat reguler, Pengabdian pada Masyarakat prioritas fakultas, Pengabdian pada Masyarakat prioritas kewirausahaan, dengan dana yang cukup memadai.

Hasil observasi yang telah dilakukan tim pengabdian mendapatkan keterangan bahwa meskipun kedua UKM telah berupaya menitipkan barang hasil produski mereka ke pengepul dan mengikuti pameran-pameran periodik diluar Kabupaten Buton sebagai bagian dari usaha promosi kepada masyarakat luar namun tingkat penjualan mereka tersebut masih sangat kecil peminat, sehingga hal ini berakibat pada tidak maksimalnya produksi kain tenun. Masalah lain yang masih dihadapi pengrajin adalah kendala informasi pemasaran yang terbatas. Saat mengikuti pameran, hanya pesanan-pesanan kecil dari daerah lokal-lah yang langsung ke pengrajin, dan bila ada pesanan dari luar daerah dan luar negeri, itupun melewati pedagang besar atau eksportir dari Jakarta, sehingga omset yang diterima oleh pengrajin tidak maksimal. Meskipun demikian, kedua UKM ini tidak mudah putus asa, mereka terus melakukan berbagai upaya untuk lebih mamajukan usaha kerajinannya.

Seiring dengan berkembangnya usaha ini, dengan kemampuan seadanya mereka terus berusaha untuk dapat selalu berproduksi. Kedua UKM terus berusaha membangun hubungan baik dengan berbagai pihak dalam rangka untuk pemasaran produk kerajinan yang dihasilkan. Selama ini mereka telah berhubungan baik dengan dinas perindustrian, perdagangan dan koperasi Kabupaten Buton. Namun hubungan tersebut sebatas memberikan informasi kepada pengrajin bilamana ada kegiatan-kegiatan pameran. Kedua UKM sangat berharap untuk dapat menjalin hubungan kerjasama dengan pihak perguruan tinggi agar dapat memberikan bantuan baik berupa pelatihan, penerapan teknologi, perbaikan manajemen, sistem pemasaran yang efektif sehingga dapat meningkatkan produktivitas usaha yang mereka jalankan.

\section{Permasalahan Mitra}

Berdasarkan analisis situasi di atas, kedua UKM pengrajin ini, dalam perkembangannya masih mengalami berbagai permasalahan. Permasalahan tersebut yaitu:

1. Manajemen usaha yang dijalankan masih sangat sederhana.

2. Belum memiliki sistem pembukuan yang baik dan rapi, sehingga keuntungan maupun kerugian tidak dapat terdeteksi dengan baik.
3. Jaringan pemasaran yang dimiliki sangat terbatas.

4. Belum memiliki kemampuan penggunaan Teknologi Informasi sebagai media promosi dan pemasaran.

Melihat betapa kompleksnya permasalahan yang dihadapi UKM mitra dan keterbatasan dari tim pelaksana PKM, maka perlu prioritas terhadap permasalahan yang akan diatasi melalui kegiatan Ipteks ini.

Berdasarkan analisis kebutuhan yang telah dilakukan dengan berdiskusi dengan kedua UKM dan mempertimbangkan kemampuan tim pelaksana PKM, maka permasalahan yang diprioritaskan untuk diatasi melalui kegiatan PKM ini adalah:

1. Penggunaan teknologi informasi sebagai media promosi dan pemasaran produk;

2. Perbaikan sistem manajemen.

Informasi mengenai beberapa permasalahan yang dihadapi oleh kedua UKM tersebut tentunya harus sesegera mungkin untuk diatasi sebagai salah satu solusi pengembangan usaha kecil dan menengah. Tim pengusul pengabdian sebagai bagian dari masyarakat yang kebetulan berkecimpung dalam dunia pendidikan, merasa terpanggil untuk ikut membantu memberikan solusi terhadap permasalahan yang dihadapi kedua UKM tersebut.

Melalui program usulan kegiatan PKM ini dan berdasarkan analisis kebutuhan yang telah dilaksanakan, tim pengabdianmenentukan tujuan utama dari permasalahan tersebut dengan sentuhan Ipteks, yaitu melalui kegiatan pokok:

1. Memperluas jaringan Promosi dan pemasaran mitra;

2. Peningkatan kemampuan manajerial mitra.

Diharapkan manfaat yang nantinya diperoleh mitra dari pelaksanaan ketiga kegiatan pokok tersebut, diantaranya:

1. Mempunyai media promosi yang efektif dan efisien serta memiliki jaringan pemasaran yang lebih luas dengan teknik pemasaran yang murah dan cepat.

2. Menguasai kompetensi manajemen usaha untuk menjalankan bisnisnya, sehingga bisa membuat strategy marketing sendiri.

3. Kedua UKM akan memiliki kemandirian dalam hal proses produksi, promosi, pemasaran dan menjalankan usahanya.

4. Mengurangi ketergantungan kedua UKM kepada pihak lain.

5. Meningkatkan omzet pendapatan kedua UKM.

Adapun rencana kegiatan yang diusulkan untuk mencapai tujuan di atas adalah sebagai berikut:

1. Pelatihan penggunaan media online dan media offline untuk mendukung promosi dan pemasaran produk kerajinan. 
2. Pelatihan manajemen usaha untuk memperbaiki sistem manajemen usaha yang dijalankan.

\section{METODE}

Metode pendekatan yang digunakan dalam kegiatan ini berupa pelatihan dan pendampingan tentang penggunaan media online sebagai instrumen promosi dan pemasaran serta platihan manajemen usaha. Kreatifitas dan model penggunaan media online tersebut merupakan hasil penggalian dan kreasi dari tim PKM yang kemudian dilatihkan kepada kedua perajin mitra. Total waktu kegiatan pelatihan yang disertai pendampingan dilaksanakan selama enam bulan.

Rencana kegiatan dalam rangka melaksanakan solusi yang ditawarkan tersebut, secara rinci dapat dijelaskan sebagai berikut: Pelatihan yang diberikan kepada mitra mempunyai tujuan untuk memberikan tambahan pengetahuan dan keterampilan dalam rangka meningkatkan produktivitas pengrajin kain tenun tradisional. Pelatihan yang dimaksud sesuai dengan apa yang dibutuhkan oleh mitra yaitu pemanfaatan media sosial dan media offline, dan manajemen usaha.

\section{HASIL DAN PEMBAHASAN}

Industri kecil Kain Tenun Buton yang menjadi mitra dalam kegiatan PKM ini adalah Usaha Kecil Menengah (UKM )“Kumaha Mandiri” dan UKM “Wabula Permai” yang keduanya berada di Desa Wabula Kecamatan Wabula Kabupaten Buton. Kedua UKM yang menjadi mitra adalah UKM kerajinan kain tenun tradisional Buton yang dimiliki oleh Ibu Hariani (UKM I) dan Ibu Wa Nuu (UKM II). Kedua UKM tersebut saling bekerja sama, terutama apabila salah satu UKM tidak dapat memenuhi jumlah pesanan, maka sebagian pesanan akan diberikan kepada UKM yang lain. UKM I memiliki tenaga kerja sebanyak 3 orang sedangkan UKM II memiliki tenaga kerja sebanyak 4 orang yang merupakan warga desa Wabula tempat UKM tersebut berada.

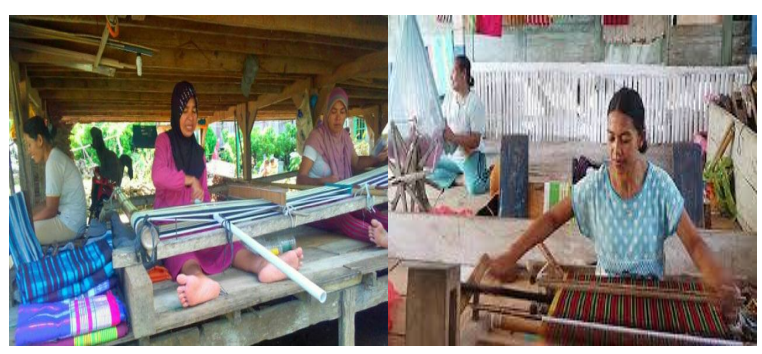

Sumber: Dokumentasi Peneliti

\section{Gambar 1. Aktifitas menenun kain tradisional Buton}

Usaha yang dijalankan kedua UKM ini merupakan usaha keluarga dan kepemilikan modal adalah modal pribadi, sehingga manajemen yang dijalankan juga masih sangat sederhana. Kedua UKM belum memiliki struktur organisasi yang baik, sehingga posisi pemilik disamping sebagai pimpinan juga merangkap sebagai manajer.
Kedua UKM belum memiliki sistem pembukuan yang baik dan rapi, sehingga tidak tampak jelas keuntungan atau kerugian yang mereka dapatkan. Selain itu, pemanfaatan media massa sebagai instrumen dalam melakukan promosi dan pemasaran belum dilakukan. Pemanfaatan kain tenun tradisional Buton ini digunakan untuk banyak hal, diantaranya: sarung, baju, topi, selendang, tas, dan sebagainya. Harga kain tradisional Buton berkisar antara Rp. 100,000.- sampai dengan Rp. 250,000.-. perbedaan harga tersebut berdasarkan motif dan bahan baku yang digunakan. Setiap bulan masing-masing UKM mampu membuat 10 helai kain tradisional dengan ukuran 2 meter. Pemasaran produk dilakukan belum dengan maksimal sebab hanya mengandalkan pesanan orang, mengikuti pameran, dan dititipkan ke pengepul.
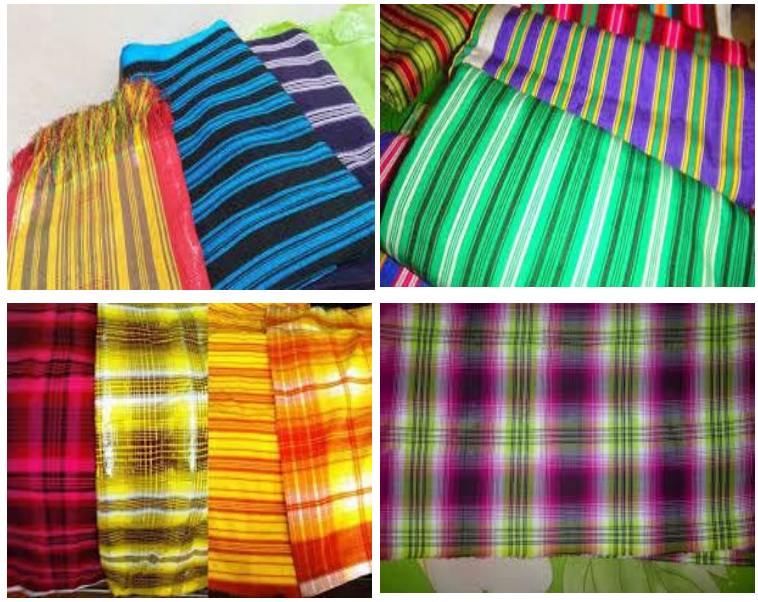

Sumber: Dokumentasi Peneliti

\section{Gambar 3. Jenis Kain Tradisional Buton}

Langkah-langkah dalam pelaksanaan pelatihan ini adalah:

a) Merumuskan materi pelatihan yang relevan;

b) Membuat jadwal pelatihan;

c) Menyiapkan alat dan bahan pelatihan;

d) Pembagian tugas Instruktur;

e) Pelaksanaan pelatihan; dan

f) Melaksanakan evaluasi.

Kegiatan Program Kemitraan Masyarakat ini telah dilaksanakan dengan sasaran dua mitra kelompok usaha pengrajin tenun tradisional yang berlokasi di Desa Wabula Kecamatan Wabula Kabupaten Buton Provinsi Sulawesi Tenggara. Adapun tahapan-tahapan kegiatan yang telah dilakukan adalah sebagai berikut:

1. Survey lokasi kegiatan yang bertujuan untuk memastikan kelayakan lokasi sesuai dengan yang telah ditetapkan oleh tim PKM;

2. Sosialisasi kepada kelompok mitra sasaran kegiatan PKM terkait teknis pelaksanaan kegiatan tersebut;

3. Peninjauan tempat pelaksanaan kegiatan pelatihan dengan memastikan kelayakan tempat pelatihan agar berjalan dengan lancar;

4. Melakukan identifikasi terhadap kebutuhan peralatan yang dibutuhkan selama kegiatan PKM berlangsung; 
5. Mempersiapkan materi-materi pelatihan dan pembagian tugas tim;

6. Melaksanakan kegiatan pelatihan untuk materi pelatihan pertama yakni pemanfaatan tekonologi informasi dan komunikasi dengan susunan materi pelatihan sebagai berikut:

a. Perkembangan teknologi informasi dan komunikasi;

b. Jenis-jenis media sosial;

c. Praktek pemanfaatan/pembuatan akun media sosial dengan konten pengenalan produk hasil kerajinan kelompok mitra.

7. Melaksanakan kegiatan pelatihan kedua tentang Manajemen usaha yang bertujuan untuk meningkatkan pengetahuan dan kemampuan manajemen usaha terutama manajemen pemasaran dalam rangka meningkatkan pendapatan usaha. Pelatihan manajemen usaha yang dilaksanakan berisi antara lain: pelatihan kewirausahaan, pelatihan pembukuan usaha kecil/ menengah, dan pelatihan manajemen pemasaran.

Sebelum dilaksanakannya kegiatan pengabdian ini, tidak ada aktifitas pembukuan yang dilakukan oleh kelompok mitra. Kegiatan pencatatan atau pembukuan hanya yang dilakukan hanya sebatas menghitung jumlah pesanan dan harga dari setiap pesanan. Tidak pernah diketahui catatan rugi-laba dari setiap transaksi jual-beli.

Sebelum dilaksanakannya kegiatan pelatihan kewirausahaan, terlebih dahulu mempersiapkan sumber daya yang harus dimiliki oleh tim pengabdian, terutama ketersediaan instruktur bidang manajemen, selanjutnya melihat tingkat kemampuan dari peserta pelatihan sehingga akan ditemukan kebutuhan materi-materi dalam pelatihan.

Pelatihan kewirausahaan/manajemen usaha menitik beratkan pada peningkatan pengetahuan dasar tentang pembukuan, pengetahuan tentang pemanfaatan teknologi informasi, dan peningkatan keterampilan pengrajin atau kelompok mitra agar berdampak pada pengembangan usaha.

\section{SIMPULAN}

Berdasarkan hasil evaluasi terhadap kegiatan pelatihan pertama yakni pelatihan pemanfaatan teknologi informasi dan komunikasi (penggunaan media sosial), terlihat bahwa anggota kelompok mitra telah memiliki pengetahuan tentang jenis-jenis media sosial dan kemampuan membuat akun media sosial yang apat digunakan untuk mempromosikan atau menjual hasil kerajinan kain tradisional mereka melalui dunia maya.
Hal atau komponen-komponen lainnya yang menunjang keberhasilan kegiatan ini adalah: ketersediaan sumber daya manusia (fasilitator/pemateri) yang memiliki kompetensi di bidang teknologi informasi dan komunikasi, dan manajemen yang bertanggungjawab memberikan pengetahuan dan keterampilan kepada para pengrajin atau kelompok mitra. Penyiapan dan pemberian materi kepada mitra yang sesuai dengan kebutuhan kelompok mitra sangat menentukan peningkatan pengetahuan dan keterampilan mitra. Selain itu, antusiasme dan partisipasi mitra yang sangat tinggi untuk mengikuti kegiatan pengabdian ini menjadi faktor pendukung keberhasilan kegiatan tersebut. Kelompok mitra sangat banyak membantu tim pengabdian dalam mempersiapkan teknis pelaksanaan kegiatan.

\section{UCAPAN TERIMA KASIH}

Terima kasih kepada Direktorat Riset dan Pengabdian Masyarakat, Direktorat Jenderal Penguatan Riset dan Pengembangan Kementerian Riset Teknologi dan Pendidikan Tinggi Republik Indonesia yang telah memberikan kesempatan kepada kami untuk mendapatkan bantuan pendanaan kegiatan Pengabdian kepada Masyarakat ini.

\section{DAFTAR PUSTAKA}

Biro Pusat Statistik. (2011). Pengukuran dan Analisis Ekonomi Kinerja Penyerapan Tenaga Kerja. Nilai Tambah, dan Eksport Usaha kecil Menengah serta peranannya terhadap Tenaga kerja Nasional dan Produk Domestik Bruto. Jakarta.

Disperidagkop. (2016). Profil Industri Kecil dan Kerajinan Rumah Tangga: Tahun 2016. Buton.

Kenneth N. Wexley. (2009). Developing and Training Human Resources in Organizations.

Kuncoro, M. (2002). Analisis Spasial dan Regional: Studi Aglomerasi dan Kluster Industri Indonesia. UPPAMP YKPN: Yogyakarta.

Noer Soetrisno. (2012). Pengembangan UKM, Ekonomi Rakyat Dan Penanggulangan Kemiskinan. Jakarta.

Shujiro Urata. (2007). Policy Recommendation for SME Promotion in the Republic of Indonesia, JICA Senior Advisor to Coordination Minister of Economy, Finance and Industri. Jakarta.

Sumardjo, (2014), Teori dan Praktik Kemitraan Agribisnis. Penebar Swadaya: Jakarta.

Tarsis Tarmudji. (2006). Prinsip-prinsip Wirausaha. Liberty: Yogyakarta. 